\title{
ANALISIS PENENTUAN LOKASI EVAKUASI BENCANA BANJIR DENGAN PEMANFAATAN SISTEM INFORMASI GEOGRAFIS DAN METODE SIMPLE ADDITIVE WEIGHTING
}

\author{
(Studi Kasus : Kota Surakarta) \\ Juliana Andretha Janet Lumban Batu ${ }^{1}$, Charitas Fibriani ${ }^{2}$ \\ ${ }^{1}$ Program Studi S1 Sistem Infomasi, Universitas Kristen Satya Wacana \\ ${ }^{2}$ Program Studi S2 Sistem Infomasi, Universitas Kristen Satya Wacana \\ Email: ${ }^{1} 682013074 @$ student.uksw.edu, ${ }^{2}$ charitas.fibriani@ staff.uksw.edu
}

(Naskah masuk: 29 Maret 2017, diterima untuk diterbitkan: 7 Mei 2017)

\begin{abstract}
Abstrak
Kota Surakarta merupakan kota dengan ancaman banjir yang cukup besardan kebanyakan diantaranya merupakan genangan, mengingat bahwa kondisi geografis kota Surakarta yaitu salah satunya dikelilingi oleh bantaran sungai bengawan solo. Tingginya curah hujan sewaktu-waktu dapat menyebabkan aliran sungai tidak dapat menahan debit air sehingga menyebabkan meluapnya air dan menyebabkan banjir. Upaya mitigasi dengan cara memberi peringatan dini kepada masyarakat dirasa dapat menjadi salah satu upaya dalam menekan angka kerugian sebelum bencana banjir datang. Dengan pemanfaatan Sistem Informasi Geografis serta metode Simple Additive Weighting dalam menentukan lokasi evakuasi bencana banjir maka diharapkan ketika banjir datang maka masyarakat kota Surakarta dapat memiliki persiapan lebih dini. Hal ini juga dapat membantu pihak pemerintahan terkhususnya pihak Badan Penanggulangan Bencana Daerah (BPBD) dalam melakukan evakuasi ketika banjir datang.
\end{abstract}

Kata kunci: sistem informasi geografis, simple additive weighting, mitigasi, lokasi evakuasi, surakarta.

\begin{abstract}
Surakarta is a city with a fairly high threat of flooding and most of them are puddles in some areas, considering that one of the geographical conditions of Surakarta was said that Surakarta surrounded by riverbank of bengawan solo. The river flow could not hold the water flow whenever heavy rainfall come and could possibly causing an overvlow and cause of flooding. The attempts of mitigation by giving early warning to the public is considered to be one attempts to reduce the number of losses before the flood came. With the use of Geographic Information Systems and Simple Additive weighting method to determine the great location of shelter then the people of the city of Surakarta could have early preparation before the floods come as it expected. This attempts can also help the government especially to the Badan Penanggulangan Bencana Daerah $(B P B D)$ in attempt of the evacuation when the flood came.
\end{abstract}

Keywords: geographic information system, simple additive weighting, mitigation, shelter, surakarta.

\section{PENDAHULUAN}

Banjir adalah salah satu bencana alam yang disebabkan oleh beberapa faktor alam. Faktor alam yang dimaksud diantaranya dapat berupa curah hujan yang tinggi, kelerengan tanah yang lebih rendah dari permukaan air laut maupun dikarenakan tanggul ataupun aliran sungai yang tidak mampu menahan debit air hujan.Rendahnya kesadaran manusia dalam menjaga lingkungan juga dapat dijadikan salah satu pemicu terjadinya banjir termasuk di Indonesia. (Rosyidie, 2013).

Kota Surakarta sendiri saat ini banjir sudah menjadi catatan penting di 21 kelurahan dan terdapat 6 sungai yang harus diwaspadai berdasarkan pemaparan dari Badan Penanggulangan Bencana Daerah (BPBD) kota Surakarta. Seperti pada tanggal 28-30 November 2016 banjir melanda beberapa wilayah di Surakarta salah satu diantaranya di kelurahan Sangkrah dan kelurahan Semanggi, Pasar Kliwon yang dikarenakan luapan sungai Bengawan Solo yang akhirnya mengharuskan warga di lokasi tersebut untuk menempati pengungsian di daerah bantaran sungai Bengawan Solo. (www.surakarta.go.id).

Menurut Ketua Peneliti Balitek Daerah Aliran Sungai (DAS) Bengawan Solo yaitu Endang Savitri, beliau mengatakan bahwa banjir luapan yang terjadi dikarenakan rusaknya atau kurang berfungsinya wilayah resapan air terutama di daerah hulu (Wonogiri hingga Ngawi). Iklim yang saat ini tidak menentu juga dapat dijadikan salah satu alasan terjadinya banjir dikarenakan curah hujan yang tidak pada masanya sehingga kurangnya mitigasi pada saat musim yang tidak termasuk musim penghujan seperti pada banjir di Kota Surakarta pada bulan Juni 2016 silam. Cepatnya rambatan air dan lambannya 
informasi antisipasi bencana banjir dapat menyebabkan kurang maksimalnya penekanan dampak dari banjir itu sendiri. Salah satu tindakan antisipasi yang dapat dilakukan sebelum bencana banjir datang adalah dengan menentukan lokasi evakuasi atau tempat singgah untuk pertolongan bencana banjir dan di sebarkan kepada masyarakat luas demi untuk mempercepat proses evakuasi korban bencana sehingga dapat meminimalisir kerugian dari banjir itu sendiri. Hal tersebut didukung oleh pemaparan Gatot Sutanto selaku Kepala Pelaksana Harian BPBD Surakarta yang menyebutkan bahwa penanganan banjir yang terjadi di kota Surakarta pada bulan Juni 2016 masih kurang terantisipasi baik masyarakat maupun pemerintah. (Solopos, 2016).

Berkaitan dengan pemaparan latar belakang tersebut, maka akan dimanfaatkan Sistem Informasi Geografis (SIG) dengan menggunakan fungsi Overlay dan Buffer serta dilanjutkan dengan perhitungan menggunakan metode Simple Additive Weighting (SAW) yang diharapkan dapat menentukan lokasi evakuasi terbaik agar dapat dijadikan pertimbangan serta membantu instansi terkait terkhususnya BPBD dalam rangka meningkatkan mitigasi banjir di kota Surakarta.

Output yang nantinya akan dihasilkan adalah hasil analisa yang berupa peta informasi lokasi evakuasi saat banjir tiba di kota Surakarta.

\section{KAJIAN PUSTAKA}

Penelitian tedahulu yang diguanakan sebagai salah satu acuan penelitian ini adalah berjudul "Penentuan Jalur Evakuasi, Tempat Evakuasi Sementara (TES) Beserta Kapasitasnya Di Kota Pariaman Dengan Sistem Informasi Geografis (SIG)" yang ditulis oleh Dini Purbani (2015). Penelitian ini dibuat untuk menentukan Jalur Eakuasi, Tempat Evakuasi Sementara (TES) Beserta Kapasitasnya dengan pemanfaatan Sistem Informasi Geografis (SIG) dalam rangka melakukan usaha mitigasi di kota Pariaman yang merupakan daerah pesisir Sumatera Barat yang dekat dengan lokasi sumber gempa dan tsunami. Usaha mitigasi tersebut yaitu berupa pembuatan Tempat Evakuasi Sementara (TES) di daerah pesisir yang dapat dijangkau dengan cepat oleh masyarakat ketika tsunami datang. Penentuan jalur tercepat juga dianalisa mengingat pentingnya efektifitas jangkauan menuju lokasi evakuasi dikarenakan tsunami yang datang dengan cepat. Penelitian ini bertujuan untuk mengupayakan mitigasi diatas dengan pemanfaatan SIG. Secara konseptual penelitian terdahulu memiliki beberapa kesamaan dengan penelitian ini diantaranya memiliki kesamaan dalam upaya mitigasi, pemanfaatan SIG sebagai metode pengolahan data spasial untuk pengambilan keputusan terkait lokasi evakuasi. Namun disisi lain memiliki perbedaan diantaranya pada penelitian terdahulu lebih terfokus kepada daerah yang terklasifikasi sebagai daerah rawan bencana sedangkan pada penelitian ini dilakukan dikeseluruhan kota Surakarta. Perbedaan lainnya adalah penelitian terdahulu sudah melakukan perhitungan terkait jalur tercepat yang dapat dilewati, namun penelitian ini masih terfokus kepada penentuan lokasi evakuasi saja.

Penelitian lainnya berjudul "Pemetaan Wilayah Risiko Bencana BanjirKabupaten Kudus Berdasarkan AspekAncaman, Kerentanan, dan KapasitasBerbasis Sistem Informasi Geografis" yang betujuan untuk menganailis dan memetakan daerah resiko banjir di Kabupaten Kudus yang nantinya digunakan sebagai acuan untuk melakukan tindakan mitigasi yang diantaranya yaitu penanggulangan dan pengurangan resiko banjir di Kabupaten Kudus. Penelitian ini memanfaatkan SIG dalam poses pemetaan resiko banjir. Hal yang sama yang dilakukan pula dengan penelitian ini ialah analisis menggunakan analisis spasial yang diantaranya yaitu overlay dan buffer dalam pengambilan keputusan. Penelitian terdahulu ini dilakukan pula penentuan parameter tekait apa saja yang berkaitan dengan kerentanan bencana banjir, konsep serupa dilakukan dalam penelitian ini yaitu menentukan parameter sesuai dengan hal-hal yang berkaitan dengan kesesuaian lokasi evakuasi banjir. (Chernovita, 2013).

Banjir adalah salah satu bencana alam yang mana terjadi dikarenakan meluapnya volume air yang mengakibatkan meluapnya air ke daratan maupun suatu daerah. (UU Nomor 24 Tahun 2007). Meluapnya debit air dapat dikarenakan tingginya curah hujan sehingga tidak dapat dibendung oleh sungai maupun tanggul.

Ahli hidrologi banjir di Indonesia membagi banjir menjadi 3 jenis diantaranya: akibat dari peluapan sungai yang mana aliran air tidak dapat menampun jumlah debit air yang kemudian menyebabkan air akan turun ke daerah dataran banjir. Kemudian terdapat banjir lokal yang terjadi akibat jumlah debit air yang tinggi dan kondisi tanah yang sulit melakukan penyerapan air. Jenis terakhir ialah banjir akibat pasang surut ait laut yang terjadi karena tinggi permukaan air laut meningkat yang menyebabkan kondisi aliran air pada muara sungai berbeda sepeti saat kondisi laut surut dikarenakan aliran sungai menjadi lambat sehingga aliran sungai tidak dapat menahan debit air dan akan mengalir ke luar sungai.

Kerugian yang dapat disebabkan oleh bencana banjir sendiri dapat berupa terancamnya keselamatan masyarakat baik secara fisik maupun psikis serta kerugian material lain. (Chernovita, 2013).

Perlunya upaya mitigasi banjir untuk mencegah atau mengurangi resiko dari bencana tersebut. Mitigasi sendiri adalah upaya penekanan dampak bencana dengan upaya menyadarkan masyarakat 
akan bahaya bencana. (Undang-undang Republik Indonesia Nomor 2 Tahun 2007 Tentang Penanggulangan Bencana). Kegiatan mitigasi tersebut dapat dilakukan dengan melalui pelaksanaan penataan ruang, pengaturan pembangunan, pembangunan infrastruktur, tata bangunan dan penyelenggaraan pendidikan, penyuluhan, dan pelatihan baik secara konvensional maupun modern. (Undang-undang Republik Indonesia Pasal 47 Nomor 2 Tahun 2007 Tentang Penanggulangan Bencana). Salah satu upaya yang dapat dilakukan dalam tahap kesiapsiagaan sebelum terjadinya banjir ialah dengan menyiapkan tempat pengungsian yang diperkirakan aman dari banjir dan mempu menampung masyarakat yang akan mengungsi bila banjir terjadi. (Ilmu Geografi, 2016).

Dengan melakukan mitigasi bencana maka diharapkan dapat mengurangi tingkat resiko bencana yaitu seperti memperkecil ancaman bencana, mengurangi kerentanan kawasan terancan dan meningkatkan kapasistas kawasan terancam.

Sistem Infomasi Geografis merupakan suatu sistem dengan basis komputer yang dapat mengolah data geografis yaitu dengan memasukkan data, mengolah data (menyimpan dan mengambil data), manipulasi dan analisis data, serta keluaran sebagai hasil akhir (output). Hasil akhir (output) akan menjadi salah satu pengambil keputusan dalam kasus tertentu terkait geografis. (Chernovita, 2013).

SIG dapat dibagi menjadi dua klasifikasi yaitu maual dan otomatis. Letak pebedaannya dapat terlihat dari teknis pengelolaannya yang mana pada manual pengerjaannya yaitu dengan menggabungkan data berupa peta, media lembar transparan untuk tumpang susun (overlay) seperti pada Gambar 1. Seluruh data tersebut dapat diolah dan dianalisis secara manual tanpa menggunakan komputer. Bebeda halnya dengan sistem otomatis yang dapat mengolah data yang telah melalui proses digitasi. sumber data dapat berupa citra satelit maupun foto udara yang telah terdigitasi serta peta tematik yang telah tedigitasi pula. (Tanaamah, 2013).

Analisis overlay sendiri merupakan operasi spasial yang terkomputerisasi yang terjadi pada dua atau lebih layer peta yang telah terkoodinat. Dalam fungsi geoprocessing, titik perpotongan geometris dapat digunakan untuk menggabungkan, memodifikasi maupun memperbaharui fitur pada hasil dataset peta. (ESRI).

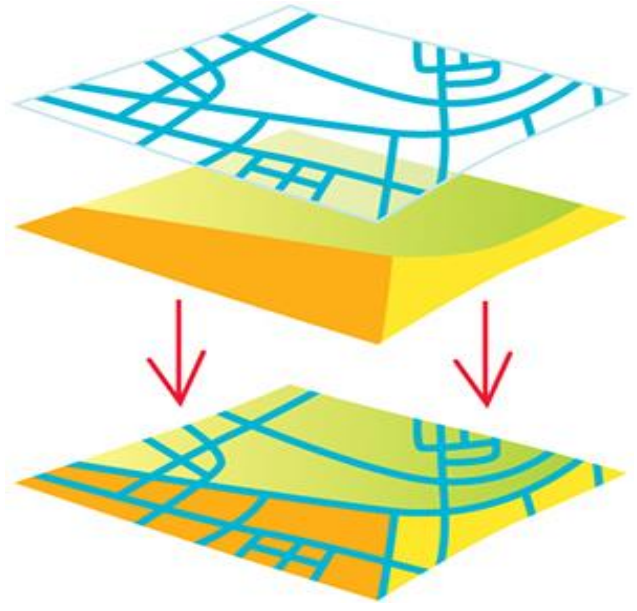

Gambar 1. Overlay Map Layer (ESRI)

Metode Simple Additive Weighting (SAW) dapat pula disebut sebagai metode penjumlahan terbobot. Pada dasarnya metode SAW digunakan untuk mencari penjumlahan terbobot dari rating kinerja pada setiap alternative di setiap kriteria yang ada. Alternative yang ada dihauskan untuk melalui poses normalisasi matrik keputusan (X) dengan berdasarkan skala yang berasal dari bobot masingmasing atribut. Berikut merupakan langkah penyelesaian dengan menggunakan metode SAW :

1. Menentukan $\mathrm{Ci}$ yang merupakan kriteria saja yang akan dijadikan acuan dalam pengambilan keputusan.

2. Menentukan rating kecocokan setiap alternatif pada setiap kriteria.

3. Membuat matriks keputusan berdasarkan (Ci), kemudian kemudian melakukan normalisasi matriks berdasarkan persamaan yang disesuaikan dengan jenis atribut (atribut keuntungan ataupun atribut biaya) sehingga diperoleh matriks ternormalisasi R. rumus yang digunakan untuk melakukan normalisasi adalah seperti Pesamaan (1) berikut:

$R i j$

$=\left\{\begin{array}{c}\frac{\mathrm{X}_{\mathrm{ij}}}{\operatorname{Max}_{\mathrm{i}} \mathrm{X}_{\mathrm{ij}}} \text { Jika } \mathrm{j} \text { adalah atribut keuntungan (benefit) } \\ \frac{\mathrm{Min}_{\mathrm{i}} \mathrm{X}_{\mathrm{ij}}}{\mathrm{X}_{\mathrm{ij}}} \text { Jika } \mathrm{j} \text { adalah atribut biaya (cost) }\end{array}\right.$

Dengan keterangan:

$$
\begin{array}{ll}
\mathrm{R}_{\mathrm{ij}} & =\text { Rating kinerja ternormalisasi } \\
\operatorname{Max}_{\mathrm{ij}} & \text { nilai maksimal dari setiap baris } \\
& \text { dan kolom } \\
\operatorname{Min}_{\mathrm{ij}} & \text { nilai maksimal dari setiap baris } \\
& \text { dan kolom } \\
& =\text { baris dan kolom dari matriks }
\end{array}
$$

4. Hasil akhir diperoleh dari proses perangkingan yaitu penjumlahan dari perkalian matriks 
ternormalisasi $\mathrm{R}$ dengan vektor bobot sehingga diperoleh nilai terbesar yang dipilih sebagai alternatif terbaik (Ai) sebagai solusi. $\mathrm{r}_{\mathrm{ij}}$ adalah rating kinerja ternormalisasi dari alternatif $\mathrm{Ai}$ pada atribut $C_{j} ; i=1,2, \ldots \ldots . m$ dan $j=1,2 \ldots \ldots, n$. Nilai preferensi untuk setiap alternatif $\left(\mathrm{V}_{\mathrm{i}}\right)$ diberikan sebagai rumus pada Persamaan(2) berikut :

$$
V_{i}=\sum_{j=l}^{n} W_{j} r_{i j}
$$

Dengan keterangan:

$\mathrm{V}_{\mathrm{i}}=$ nilai akhir dari alternatif

$\mathrm{W}_{\mathrm{j}}$ = bobot yang telah ditentukan

$\mathrm{R}_{\mathrm{ij}}=$ normalisasi matriks

Nilai Vi yang lebih besar mengindikasikan bahwa alternatif Ai lebih terpilih.

\section{METODOLOGI}

Pada bab ini akan menjelaskan mengenai metode penelitian ini dilaksanakan. Gambar 4 dibawah ini akan menjelaskan tahapan metode penelitian dalam pencapaian tujuan dari penelitian.

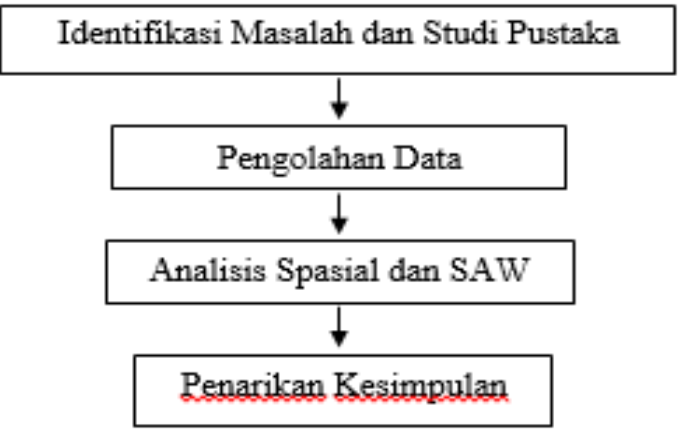

Gambar 2. Tahapan Penelitian

\subsection{Identifikasi Masalah dan Studi Pustaka}

Tahapan penelitian ini dimulai dengan mengidentifikasi masalah yang terjadi di Kota Surakarta yang mana dilakukan dengan metode wawancara kepada pihak BPBD Surakarta mengenai permasalahan banjir beserta upaya mitigasinya. Hasil wawancara tersebut diperoleh temuan-temuan serta batasan dari penelitian ini. Hasil wawancara tersebut menjelaskan mengenai kriteria Kota Surakarta secara geografis dalam hal bencana banjir serta variabel apa saja yang dapat menjadikan suatu lokasi dikatakan layak untuk dijadikan lokasi shelter sesuai dengan kriteria secara geografis kota Surakarta.

Studi pustaka dilakukan untuk penggunaan literatur yang berkaitan dengan penelitian ini diantaranya studi pustaka mengenai banjir, mitigasi, sistem informasi geogafis, serta kriteria dari kota Surakarta terkait bencana banjir.

\subsection{Pengolahan Data}

Terdapat dua jenis data dalam penelitian ini diantaranya data primer dan sekunder. Data primer didapatkan melalui wawancara dengan pihak BPBD terkait dengan kriteria kota Surakarta secara geografis mengenai bencana banjir serta persyaratan suatu lokasi dikatakan layak sebagai lokasi evakuasi bencana banjir. Persyaratan tersebut diantaranya berupa :

a. Aman/relatif aman dari kemungkinan terjadi bencana serupa.

b. Letaknya strategis mudah dijangkau oleh umum dengan dukungan komunikasi dan akses jalan, serta transportasi memungkinkan.

c. Dekat dengan sumber air dan tersedianya MCk.

d. Tidak bermasalah dalam penggunaan dan pemanfaatan atas status tanah.

e. Mendekatkan kepada fasilitas umum dan social lainnya.

Persyaratan tersebut masih harus disesuaikan dengan kondisi riil dari Kota Surakata aga dapat dimodelkan untuk pengambilan data sekunder selanjutnya. sedangkan data sekunder yang digunakan terdiri dari beberapa peta yang diterjemahkan melalui data primer. Data tersebut adalah berupa Peta Administrasi, Peta Bencana Banjir, Peta Tata Guna Lahan, Peta Curah Hujan Kota Surakarta. Peta tersebut telah memiliki atribut yang berisi field data terkait informasi sesuai dengan masing-masing peta. Data-data tersebut digunakan untuk pengambilan keputusan dalam overlay dan metode SAW.

\subsection{Analisis Spasial dan SAW}

Data sekunder kemudian diolah menggunakan analisis spasial dengan fungsi Overlay dan Buffer pada peta tertentu yang menghasilkan data temuan baru yang selanjutnya diolah menggunakan metode SAW. Berikut meupakan Tabel 1 menjelaskan mengenai kriteria lokasi yang digunakan berdasarkan penyesuaian dengan data primer :

Tabel 1. Kriteria lokasi berdasarkan data primer.

\begin{tabular}{ll}
\hline \multicolumn{1}{c}{ Kriteria } & \multicolumn{1}{c}{ Penilaian } \\
\hline Bencana \\
$\begin{array}{l}\text { Banjir dan } \\
\text { Serupa }\end{array}$ & $\begin{array}{l}\text { Bukan daerah rawan bencana } \\
\text { banjir dan longsor. }\end{array}$ \\
Jarak Jalan & $\begin{array}{l}\text { Semakin dekat dengan akses jalan } \\
\text { maka semakin baik }\end{array}$ \\
Jarak & $\begin{array}{l}\text { Semakin dekat dengan daerah } \\
\text { permukiman maka semakin baik. }\end{array}$ \\
Pemukiman & $\begin{array}{l}\text { Semakin jauh dengan daerah aliran } \\
\text { Jarak DAS }\end{array}$ \\
Tata Gungai maka semakin baik. & - Merupakan \\
Lahan & terbuka/lapangan. \\
(Landuse) &
\end{tabular}


- Meupakan bangunan milik pemerintah kota (dalam hal ini dapat berupa kantor kelurahan).

- Merupakan Gedung Sekolah Maupun Bangunan Keagamaan (Gereja, Masjid dll.)

Curah Semakin rendah curah hujan maka Hujan semakin baik.

Data sekunder yang ditemukan kemudian dicocokkan dengan kriteria yang ada. Table 2 akan menjelaskan mengenai data sekunder yang mewakili kriteria yang ada :

Tabel 2. Relasi Kriteria dan Data Sekunder.

\begin{tabular}{cc}
\hline Kriteria & Data Sekunder \\
\hline Bencana Banjir dan Serupa & Peta Bencana Banjir \\
Jarak Jalan & Peta Ruas Jalan \\
Jarak Pemukiman & Peta Permukiman \\
Jarak DAS & Peta Aliran Sungai \\
Tata Guna Lahan (Landuse) & Peta Landuse \\
Curah Hujan & Peta Curah Hujan \\
\hline
\end{tabular}

Didalam SAW sendiri dilakukan pembobotan pada masing-masing kriteria yang digunakan untuk melakukan penjumlahan terbobot pada perhitungan SAW.Hasil pembobotan telah disesuaika dengan data primer yaitu hasil wawancara dengan pihak BPBD Kota Surakarta serta BMKG kota Semarang. Pembobotan akan lebih di jelaskan pada Tabel 3-8 berikut :

Tabel 3. Pembobotan kriteria Bencana Banjir dan Serupa.

\begin{tabular}{ccc}
\hline No & Kelas & Bobot \\
\hline 1 & Rendah & 4 \\
2 & Sedang & 3 \\
3 & Tinggi & 2 \\
4 & Sangat Tinggi & 1 \\
\hline
\end{tabular}

Tabel 4. Pembobotan kriteria Jarak Jalan.

\begin{tabular}{ccc}
\hline No & Jarak Buffer & Bobot \\
\hline 1 & $0-500 \mathrm{~m}$ & 4 \\
2 & $500-1000 \mathrm{~m}$ & 3 \\
3 & $1000-2000 \mathrm{~m}$ & 2 \\
4 & $2000-2500 \mathrm{~m}$ & 1 \\
\hline
\end{tabular}

Tabel 5. Pembobotan kriteria Jarak Pemukiman.

\begin{tabular}{ccc}
1 & $0-10 \mathrm{~m}$ & 4 \\
2 & $10-250 \mathrm{~m}$ & 3 \\
3 & $250-500 \mathrm{~m}$ & 2 \\
4 & $500-1000 \mathrm{~m}$ & 1 \\
\hline
\end{tabular}

Tabel 6. Pembobotan kiteria Jarak DAS.

\begin{tabular}{cllc}
\hline No & Kelas & Jarak Buffer & Bobot \\
\hline 1 & Aman & $250 \mathrm{~m}-500 \mathrm{~m}$ & 4 \\
2 & Agak rawan & $150 \mathrm{~m}-250 \mathrm{~m}$ & 3 \\
3 & Rawan & $50 \mathrm{~m}-100 \mathrm{~m}$ & 2 \\
4 & sangat rawan & $0-50 \mathrm{~m}$ & 1 \\
\hline
\end{tabular}

Tabel 7. Pembobotan kriteria Tata Guna Lahan (Landuse).

\begin{tabular}{clc}
\hline No & \multicolumn{1}{c}{ Kelas } & Bobot \\
\hline 1 & $\begin{array}{l}\text { Lahan Terbuka (Lapangan \& } \\
\text { Tanah Terbuka) }\end{array}$ & 4 \\
2 & $\begin{array}{l}\text { Bangunan Pemerintah Kota } \\
\text { (Kelurahan) }\end{array}$ & 3 \\
3 & Sekolah & 2 \\
4 & Tempat Ibadah & 1 \\
\hline
\end{tabular}

Tabel 8. Pembobotan kriteria Curah Hujan.

\begin{tabular}{ccc}
\hline No & Kelas & Bobot \\
\hline 1 & $151-200 \mathrm{~mm}$ & 4 \\
2 & $201-300 \mathrm{~mm}$ & 3 \\
3 & $301-400 \mathrm{~mm}$ & 2 \\
4 & $401-500 \mathrm{~mm}$ & 1 \\
\hline
\end{tabular}

Berdasarkan pembobotan kriteria pada tabel diatas, langkah selanjutnya adalah menentukan range skor kelayakan lokasi evakuasi. Untuk itu diperlukan penjumlahan skor total pada hasil proses analisis spasial ovelay yang telah dilakukan sebelumnya dan menentukan total skor terendah dan tertinggi untuk menentukan range skor kelayakan lokasi.Total skor akan diklasifikasikan menjadi lima himpunan kelayakan yaitu seperti pada tabel 8 berikut :

Tabel 9. Range skor kelayakan lokasi.

\begin{tabular}{cc}
\hline Skor Total & Kelayakan \\
\hline $21-25$ & Sangat Layak \\
$16-20$ & Layak \\
$11-15$ & Cukup \\
$6-10$ & Kurang Layak \\
$1-5$ & Tidak Layak \\
\hline
\end{tabular}


Berdasarkan range skor kelayakan diatas maka data hasil overlay yang berjumlah 8704 data disortir kembali. Data yang akan digunakan dalam pehitungan SAW merupakan data yang termasuk dalam range kelayakan dengan "Sangat Layak" yaitu dengan skor total 21-25 dengan jumlah temuan data sebanyak 83 data.

Kriteria akan diwakilkan oleh $\mathrm{C}_{\mathrm{i}}$ dalam perhitungan SAW. Masing-masing kriteria akan diberikan bobot sesuai dengan data primer yang ada. Berikut pada tabel 10 merupakan pemaparan pembobotan tiap kriteria :

Tabel 10. Pembobotan tiap kriteria untuk pengambilan keputusan.

\begin{tabular}{llc}
\hline $\mathbf{C}_{\mathbf{i j}}$ & \multicolumn{1}{c}{ Kriteria } & Bobot \\
\hline $\mathrm{C} 1$ & Bencana Banjir dan Serupa & $25 \%$ \\
$\mathrm{C} 2$ & Jarak Terhadap Jalan Umum & $15 \%$ \\
$\mathrm{C} 3$ & Jarak Terhadap Pemukiman & $10 \%$ \\
$\mathrm{C} 4$ & Jarak Terhadap DAS & $20 \%$ \\
$\mathrm{C} 5$ & Curah Hujan & $15 \%$ \\
$\mathrm{C} 6$ & Landuse & $15 \%$ \\
\hline
\end{tabular}

\subsection{Penarikan Kesimpulan}

Temuan akhir dari perhitungan dengan metode SAW tersebut merupakan kesimpulan dari keseluruan penelitian yang mana akan menentukan lokasi evakuasi terbaik berdasarkan kriteria yang telah ditentukan.

\section{ANALISIS DAN PEMBAHASAN}

Penelitian ini akan menghasilkan peta dengan informasi mengenai lokasi evakuasi terbaik yang digunakan ketika banjir terjadi di Kota Surakarta. Peta tersebut dihasilkan melalui analisis spasial dengan pemanfaatan SIG dan metode SAW dengan menggunakan data primer serta sekunder.

\subsection{Analisis Spasial}

Sebelum memasuki tahap overlay dan buffer, terlebih dahulu peta harus dikonversikan kedalam peta digital dalam bentuk shapefile yang kemudian disesuaikan proyeksinya agar dapat dilakukan proses overlay dan buffer. Berikut merupakan proses overlay dari setiap peta yang menjadi variabel pengambilan keputusan.

Peta yang diproses melalui overlay adalah keseluruhan data sekunder yang telah dijelaskan pada Tabel 2. Hasil overlay adalah berupa peta dengan atribut baru sebagai alternatif calon lokasi evakuasi. Gambar 4 akan menggambarkan hasil overlay setiap layer peta :

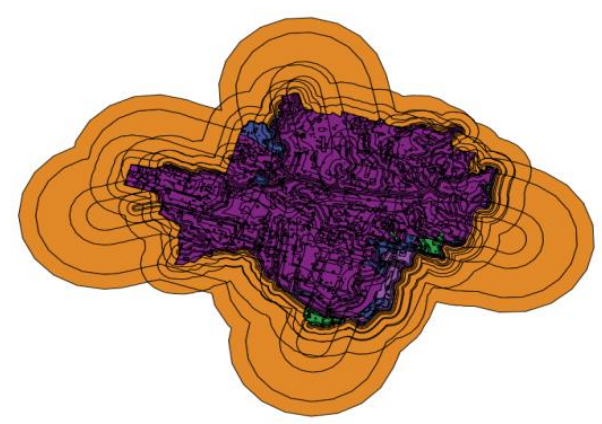

Gambar 3. Peta hasil akhir dari proses overlay Peta Bencana Banjir, Ruas Jalan, Permukiman, Aliran Sungai, Landuse dan Curah Hujan.

Peta hasil proses overlay tersebut memiliki data terkait informasi calon lokasi evakuasi yang akan disortir kembali untuk kemudian dilakukan operasi metode SAW untuk pembobotan. Berikut data dari peta hasil overlay pada Gambar 5.

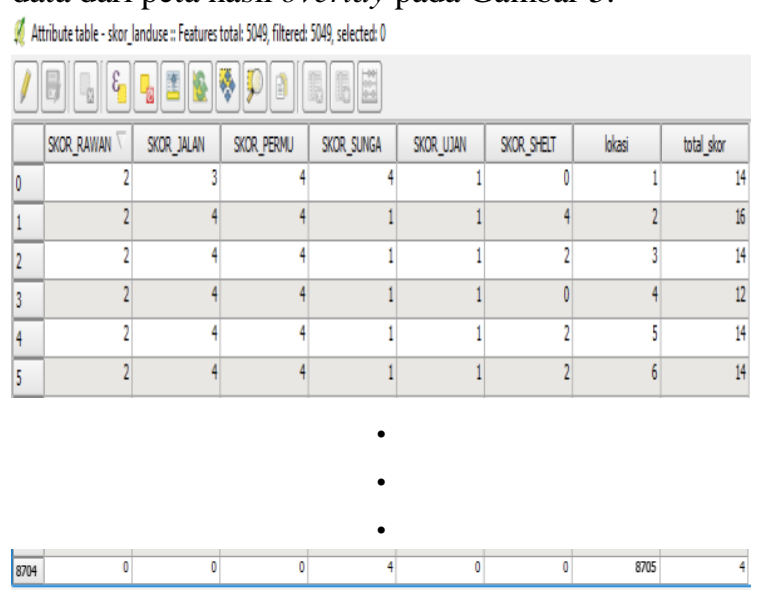

Gambar 4. Data atribut hasil dari proses overlay.

Data hasil overlay pada Gambar 5 merupakan data masing-masing layer peta sesuai dengan masing-masing peta pada Tabel 2 yang telah di overlay yang menghasilkan 8704 data baru yang menjadi alternatif calon lokasi evakuasi. Dari data tersebut kemudian diambil alternatif dengan skor kelayakan "Sangat Layak" yaitu dengan total skor 21-25 sehingga ditemukan data alternatif sebanyak 83 data. Data tersebut selanjutnya akan di analisis kembali dengan menggunakan metode SAW untuk kemudian melihat alternatif yang paling sesuai sebagai lokasi evakuasi.

\subsection{Analisis Metode Simple Additive Weighting}

Data dengan jumlah 83 data yang telah ditemukan melalui analisis overlay tersebut kemudian dianalisis kembali dengan metode SAW guna menjumlahkan secara terbobot atribut tesebut untuk menemukan altenatif terbaik. Kriteria $\left(\mathrm{C}_{\mathrm{i}}\right)$ yang akan dijadikan acuan sebelumnya telah disesuaikan pada proses sebelumnya. Berikut merupakan Tabel 1 berisi 10 dari 83 data hasil overlay yang kemudian digunakan sebagai alternative kriteria yang telah disesuaikan : 
Tabel 11. Alternatif Kriteria.

\begin{tabular}{|c|c|c|c|c|c|c|}
\hline Alternatif & C1 & $\mathrm{C2}$ & C3 & $\mathrm{C4}$ & C5 & C6 \\
\hline Lokasi 713 & 4 & 4 & 4 & 4 & 2 & 3 \\
\hline Lokasi 716 & 4 & 4 & 4 & 4 & 2 & 3 \\
\hline Lokasi 725 & 4 & 4 & 4 & 4 & 2 & 3 \\
\hline Lokasi 738 & 4 & 4 & 4 & 4 & 2 & 3 \\
\hline Lokasi 858 & 4 & 4 & 4 & 4 & 2 & 3 \\
\hline Lokasi 639 & 4 & 4 & 4 & 3 & 2 & 4 \\
\hline Lokasi 649 & 4 & 4 & 4 & 4 & 2 & 4 \\
\hline Lokasi 693 & 4 & 4 & 4 & 4 & 1 & 4 \\
\hline Lokasi 957 & 4 & 4 & 4 & 3 & 2 & 4 \\
\hline Lokasi 961 & 4 & 4 & 4 & 3 & 2 & 4 \\
\hline$\cdot$ & . & . & . & . & . & . \\
\hline . & . & . & . & . & . & . \\
\hline . & . & . & . & . & . & . \\
\hline Lokasi 3291 & 4 & 3 & 4 & 4 & 2 & 4 \\
\hline
\end{tabular}

Kemudian Kriteria altenatif dinormalisasi (R) berdasarkan kriteria $\left(\mathrm{C}_{\mathrm{i}}\right)$ dengan menyesuaikan jenis atribut apakah berjenis keuntungan atau biaya dan menyesuaikan dengan rumus yang belaku sesuai dengan jenis atribut. Normalisasi hanya dilakukan pada data dengan Berikut merupakan Tabel 2 hasil normalisasi 10 dari 83 data alternatif :

Tabel 12. Normalisasi matriks (R).

\begin{tabular}{ccccccc}
\hline Alternatif & C1 & C2 & C3 & C4 & C5 & C6 \\
\hline Lokasi 713 & 1 & 0.75 & 0.75 & 1 & 0.50 & 0.75 \\
Lokasi 716 & 1 & 0.75 & 0.75 & 1 & 0.50 & 0.75 \\
Lokasi 725 & 1 & 0.75 & 0.75 & 1 & 0.50 & 0.75 \\
Lokasi 738 & 1 & 0.75 & 0.75 & 1 & 0.50 & 0.75 \\
Lokasi 858 & 1 & 0.75 & 0.75 & 1 & 0.50 & 0.75 \\
Lokasi 639 & 1 & 0.75 & 0.75 & 0.75 & 0.50 & 1 \\
Lokasi 649 & 1 & 0.75 & 0.75 & 1 & 0.50 & 1 \\
Lokasi 693 & 1 & 0.75 & 0.75 & 1 & 1 & 1 \\
Lokasi 957 & 1 & 1 & 1 & 1 & 1 & 1 \\
Lokasi 961 & 1 & 1 & 1 & 1 & 1 & 1 \\
• &. &. &. &. &. &. \\
• &. &. &. &. &. &. \\
Lokasi &. &. &. &. &. &. \\
3291 & 1 & 1 & 0.75 & 1 & 0.5 & 1 \\
\hline
\end{tabular}

Hasil normalisasi matriks (R) diatas kemudian digunakan untuk melakukan perankingan bobot yang telah ditentukan sesuai dengan keputusan yang dijelaskan pada pada Tabel 10. Hasil dari perkalian tersebut akan menghasilkan nilai akhir dari alternatif $\left(\mathrm{V}_{\mathrm{i}}\right)$. Nilai terbesar yang akan dipilih sebagai alternatif terbaik $\left(\mathrm{A}_{\mathrm{i}}\right)$ yang dianggap sebagai lokasi ideal untuk dijadikan lokasi evakuasi bencana banjir di kota Surakarta. Data dengan alternatif terbaik yang akan dipaparkan pada Tabel 4 yang kemudian kata Lokasi akan di singkat menjadi L dan Alternatif menjadi A.

Tabel 13. Alternatif tebaik $\left(A_{I}\right)$.

\begin{tabular}{cccccccc}
\hline A & C1 & C2 & C3 & C4 & C5 & C6 & V \\
\hline L1079 & 1 & 0.75 & 0.75 & 1 & 1 & 1 & 0.94 \\
L1084 & 1 & 0.75 & 0.75 & 1 & 1 & 1 & 0.94 \\
L1085 & 1 & 0.75 & 0.75 & 1 & 1 & 1 & 0.94 \\
L1165 & 1 & 0.75 & 0.75 & 1 & 1 & 1 & 0.94 \\
L1169 & 1 & 0.75 & 0.75 & 1 & 1 & 1 & 0.94 \\
L1585 & 1 & 0.75 & 0.75 & 1 & 1 & 1 & 0.94 \\
\hline
\end{tabular}

Alternatif yang didapat memiliki 6 kriteria yang sama di masing-masing 6 data yaitu diantaranya dijelaskan pada Tabel 15:

Tabel 14. Alternatif 1

\begin{tabular}{lc}
\hline \multicolumn{1}{c}{ Kriteria } & Sub Kriteria \\
\hline Bencana Banjir dan Serupa & Rendah \\
Jarak Terhadap Jalan Umum & $0-500 \mathrm{~m}$ \\
Jarak Terhadap Pemukiman & $0-10 \mathrm{~m}$ \\
Jarak Terhadap DAS & Aman $(250-$ \\
Curah Hujan & $500 \mathrm{~m})$ \\
Landuse & $401-500 \mathrm{~mm}$ \\
\hline
\end{tabular}

Lokasi yang telah dijelaskan seluruhnya telah disesuaikan dengan setiap lokasi hasil overlay peta yang merupakan data sekunder dari penelitian ini. Setiap lokasi tersebut telah diberi bobot yang telah disesuaikan dengan pembobotan SAW yang telah diberikan di awal. Melalui perhitugan SAW tesebut maka telah ditemukan alternatif terbaik yang memiliki nilai preferensi sebesar 0.94 dengan jumlah alternatif lokasi evakuasi sebanyak 6 lokasi yang tersebar di peta kota Surakarta. Titik lokasi tersebut akan ditandai dengan polygon berwana kuning yang ada pada Gambar 6-11. Tabel yang berada pada gambar akan menjelaskan mengenai atribut terpilih sebagai lokasi yang ditandai dengan polygon kuning. 


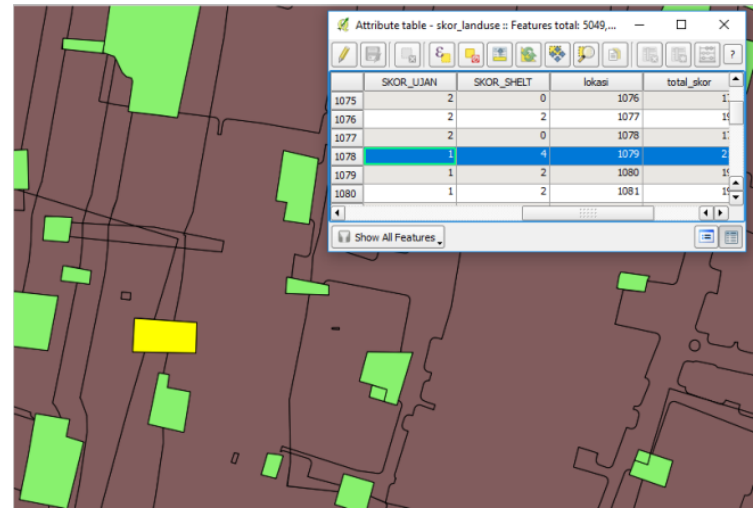

Gambar 5. Lokasi 1 berada di Kelurahan Panularan, Kecamatan Laweyan.

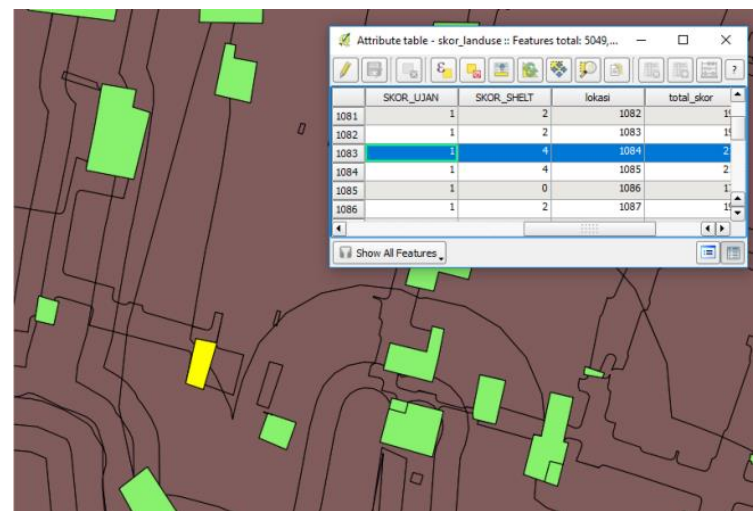

Gambar 6. Lokasi 2 berada di Kelurahan Panularan, Kecamatan Laweyan.

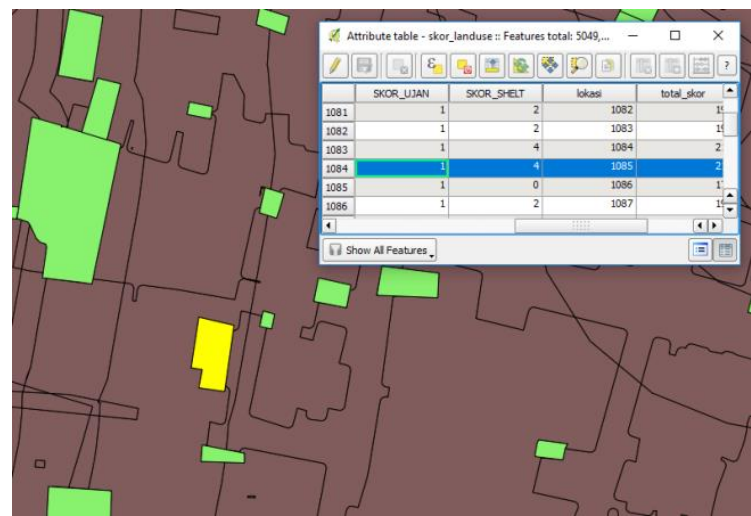

Gambar 7. Lokasi 3 berada di Kelurahan Sriwedari, Kecamatan Laweyan.

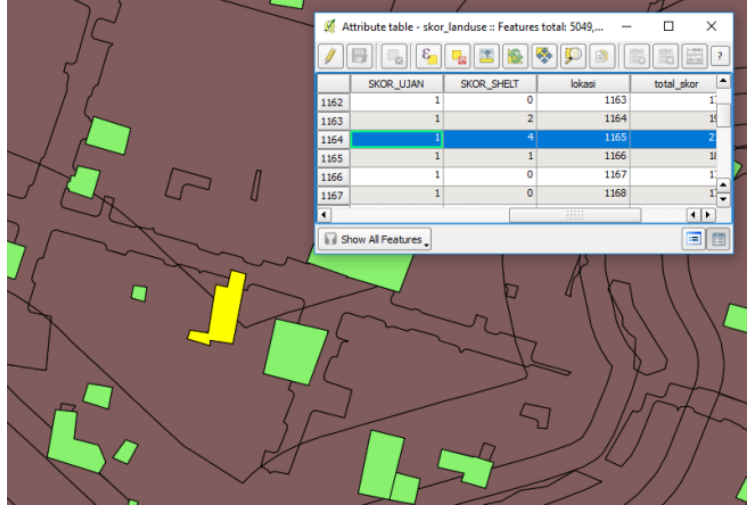

Gambar 8. Lokasi 4 berada di Kelurahan Danukusuman, Kecamatan Serengan.

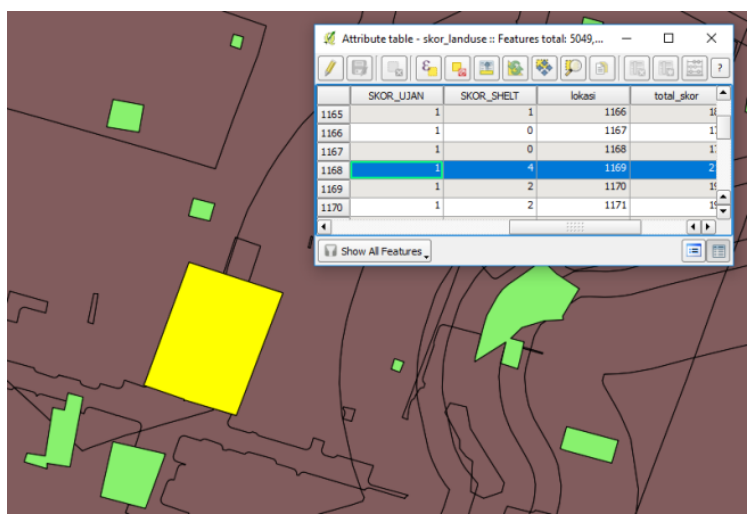

Gambar 9. Lokasi 5 berada di Keluahan Buluwarti, Kecamatan Pasar Kliwon.

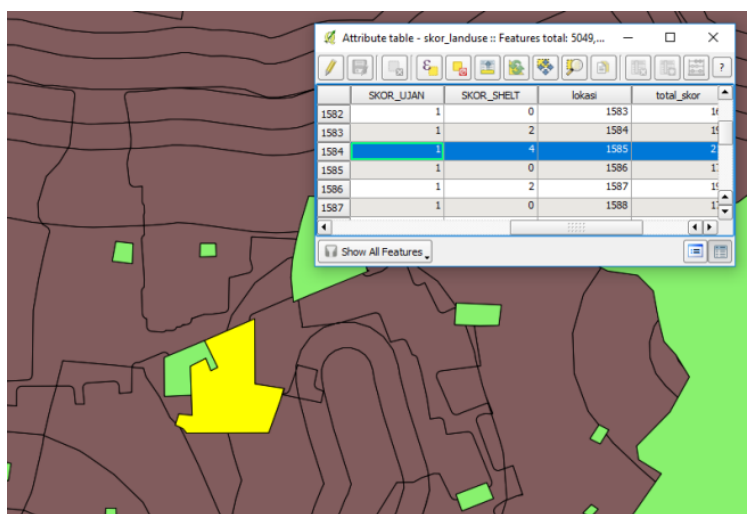

Gambar 10. Lokasi 6 berada di Kelurahan Jebres, Kecamatan Jebres.

\section{SIMPULAN}

Berdasarkan keseluruhan pembahasan maka melalui analisis menggunakan SIG dan kemudian dilanjutkan dengan penjumlahan pembobotan dengan menggunakan metode SAW untuk penentuan lokasi evakuasi guna menjadi tempat singgah sementara ketika banjir melanda di Kota Surakarta telah didapatkan temuan yaitu terdapat 6 lokasi terbaik. Keenam lokasi tersebut memiliki kriteria beserta sub kriteria yang sama yaitu yang telah dijelaskan pada Tabel 15 . 
Berdasakan keseluruhan penelitian yang telah dilaksanakan, dapat disimpulkan bahwa masih terdapat beberapa saran untuk penelitian ini kedepannya diantaranya adalah perlunya analisis terkait perbandingan jumlah pengungsi dengan lokasi evakuasi yang dituju apakah sudah mencukupi dan memadahi atau belum. Serta perlu dilakukannya penelitian terkait temuan dari penelitian ini apakah bisa digunakan pada setiap tingkatan bencana banjir yang terjadi di kota Surakarta atau tidak.

\section{DAFTAR PUSTAKA}

ArcGIS for Desktop. Understanding Overlay Analysis. Diperoleh 16 Maret 2017, dari http://desktop.arcgis.com/en/arcmap/10.3/to ols/spatial-analyst-toolbox/understandingoverlay-analysis.htm.

BNPB. Definisi Dan Jenis Bencana. Diperoleh 14 Maret 2017, dari http://www.bnpb.go.id/home/definisi.

CHERNOVITA, H.P. 2013. Pemetaan Wilayah Risiko Bencana Banjir Kabupaten Kudus Berdasarkan Aspek Ancaman, Kerentanan, dan Kapasitas Berbasis Sistem Informasi Geografis. Skripsi. Program Studi Sistem Informasi Pariwisata Fakultas Teknologi Informasi, Universitas Kristen Satya Wacana, Salatiga.

ESRI. GIS Dictionary Look Up Terms Related to GIS Operations, Cartography, and Esri Technology. Diperoleh 16 Maret 2017, dari http://support.esri.com/other-resources/gisdictionary/term/overlay.

ILMU GEOGRAFI. (2016, 17 September). Upaya Penanggulangan Banjir. Diperoleh 16 Maret 2017, dari http://ilmugeografi.com/bencanaalam/upaya-penanggulangan-banjir.

NUGRAHENI, LUSIANA RISKY. 2016. Penerapan Metode Simple Additive Weighting Untuk Penerimaan Karyawan. Repositori Universitas Dian Nuswantoro.

PRIYONO, JUMADI. 2010. Pemodelan Spatial Menggunakan Sistem Informasi Geografis (SIG) Berbasis Web Untuk Pengelolaan Wilayah Yang Terintegrasi Dengan Kebijakan Pemerintah. Seminar Nasional Penginderaan Jauh Dan Sistem Informasi Geografis.
PURBANI, DINI. 2015. Penentuan Jalur Evakuasi, Tempat Evakuasi Sementara (TES) Beserta Kapasitasnya Di Kota Pariaman Dengan Sistem Informasi Geografis (SIG). Jurnal Segara, vol. 11, no. 1.

REPUBLIK INDONESIA. 2007. Undang-Undang No. 24 Tahun 2007 tentang Penanggulangan Bencana.

ROSYIDIE, ARIEF. 2013. Banjir: Fakta dan Dampaknya, Serta Pengaruh dari Perubahan Guna Lahan. Jurnal Perencanaan Wilayah dan Kota, vol. 24, no. 3, pp.241-249.

RUDYANTO, R. 2015. Identifikasi Zona Genangan Banjir Kota Makassar Berbasis SIG. Repositori Universitas Hasanudin.

SOLOPOS. (2016, 20 Juni).BPBD Akui Penanganan Banjir Kurang Diantisipasi. Diperolah 5 Februari 2017, dari http://m.solopos.com/2016/06/20/banjirsolo-bpbd-akui-penanganan-banjir-kurangdiantisipasi-730606.

SURAKARTA.BPBD Kota Surakarta Waspadai 21 Kelurahan Rawan Banjir. Diperoleh 5 Februari 2017, dari http://www.surakarta.go.id/konten/bpbdkota-surakarta-waspadai-21-kelurahanrawan-banjir.

TANAAMAH, A. R. 2013. Perancangan Sistem Infomasi Geografis Sebaran Tanaman Pangan Berbasis Spasisal Dan Multi Tier Menggunakan Map Server. Teknologi Komputer dan Informatika, vol.9, no. 2. 